\title{
PEMODELAN SYSTEM SUPERVISORY CONTROL AND DATA ACQUISITION PADA INSTALASI PENGOLAHAN AIR (Studi Kasus : PDAM KOTA PADANG)
}

\author{
Sofika Enggari ${ }^{1}$, Deny Skylab ${ }^{2,}$ Hanna Pratiwi ${ }^{3}$ \\ ${ }^{1}$ Universitas Putra Indonesia YPTK Padang, Indonesia \\ ${ }^{2}$ PDAM Kota Padang, Indonesai \\ 3 Universitas Putra Indonesia YPTK Padang, Indonesia \\ Sofika_enggari@upiyptk.ac.id
}

\begin{abstract}
Abstrak
Inti Sari-Dalam memproduksi air bersih Perusahaan Daerah Air Minum (PDAM) membuat suatu infrastruktur yang disebut Instalasi Pengolahan Air (IPA). IPA ini memproses air baku dari air menjadi air bersih yang siap dikonsumsi. Dalam pengolahannya dilalui beberapa tahap pemrosesan mulai dari pengambilan air baku sampai air tersebut dapat di distribusikan kerumah pelanggan. Setiap tahap pemrosesan air ini perlu diawasi dan dikontrol agar kualitas, kuantitas dan kontiniunitas air bersih dapat terjaga. Kegiatan pengawasan dan pengontrolan terhadap pengolahan air ini di PDAM Kota Padang masih dilakukan secara manual. Sistem Supervisory Control And Data Acquisition (SCADA) merupakan suatu sistem pengontrolan dan pengawasan yang memamfaatkan teknologi informasi. Di negara-negara maju SCADA sudah menjadi bagian penting dalam suatu infrstruktur. SCADA di gunakan untuk mengawasi dan mengotrol jalur pipa, air, sistem transportasi, pabrik kimia dan proses lainya dalam kegiatan pabrikasi. SCADA dapat menyajikan data dan mengontrol suatu proses pengolahan/pabrikasi secara real-time. Dengan menggunakan sistem ini dapat meningkatkan kuantitas dan kualitas produksi juga efisiensi. Dalam tesis ini akan di rancang sistem SCADA untuk IPA PDAM Kota Padang. Dalam perancangan akan dilakukan pemodelan sistem dengan bahasa pemodelan Unified Modeling Language (UML).
\end{abstract}

Kata kunci: Instalasi Pengolahan Air, Data Acquisition, Pemodelan UML

\section{Pendahuluan}

Instalasi Pengolahan Air (IPA) merupakan suatu instalasi atau plant yang bertujuan untuk mengolah air baku menjadi air bersih yaitu air yang siap digunakan untuk keperluan sehari-hari. Air baku dapat bersumber dai sungai, air tanah, dan lain-lain. Perusahaan Daerah Air Minum (PDAM) Kota Padang adalah suatu badan usaha milik daerah yang bergerak dalam bidang pengolahan air bersih untuk kebutuhan masyarakat Kota Padang. PDAM menggunakan IPA sebagai alat untuk memproduksi air bersih. Saat ini pengawasan dan pengontrolan IPA tersebut masih dilakukan secara konvensional, yaitu pengawasan dan pengotrolan yang dilakukan dengan tenaga manusia dengan mengawasi dan mengtrol alat-alat produksi lansung kelokasi alat-alat tersebut dipasang. Melakukan pengawasan sebuah plant/instalasi dengan metoda konvensional tidaklah ekonomis karena memakan biaya yang tinggi, maka sistem otomatisasi dan kontrol yang terintegrasi merupakan suatu solusi yang efisien dan efektif dalam segi biaya. Normalnya 
sistem otomatisasi meningkatkan efisiensi sistem, plant monitoring, produktifitas, dan manajemen operasional sebuah plant (Bindu Pillai, et al, 2012). SCADA merupakan suatu sistem yang memungkinkan operator untuk memonitor dan mengontrol prosesproses dilokasi yang tersebar. Ada banyak fasilitas yang menggunakan SCADA salah satunya adalah fasilitas pengolahan dan distribusi air. SCADA banyak digunakan untuk menunjang keuntungan ekonomi. Jarak lokasi proses yang relatif jauh dan meningkatnya jumlah lokasi proses yang sulit diakses membuat SCADA menjadi suatu alternatif yang lebih baik dibandingkan operator atau teknisi yang lansung mengunjungi lokasi proses untuk melakukan pengontrolan dan pengawasan. Jarak dan aksesibilitas merupakan faktor utama dalam mengimplementasikan SCADA (Rajeev Kumar dan Dewal, M.L, 2010)

Oleh karena itu sistem SCADA merupakan solusi yang tepat untuk meningkatkan efisiensi pengawasan dan pengontrolan di sebuah IPA. Dengan sistem SCADA pengawasan dan pengotrolan terhadap proses pengolahan dapat dilakukan secara keseluruhan dalam suatu unit kontrol yang terpusat, sehingga tidak dibutuhkan lagi operator atau petugas untuk mengunjungi lansung ke lokasi- lokasi pengolahan air untuk melakukan pengawasan atau pengontrolan.

SCADA merupakan suatu perangkat lunak yang bertujuan untuk melakukan pengontrolan dan pengawasan proses industri. Ada beberapa pendekatan- pendekatan untuk desain perangkat lunak. Menurut Qasim Siddique (2010), UML (Unified Modeling Language) menjandi standar bahasa pemodelan yang dapat memodelkan sistem yang terdeistribusi. UML menjadi standar de facto industri yang berkembang dibawah naungan OMG (Object Managment Group). UML menggabungkan teknik-teknik terbaik dari data modeling, business modeling, object modeling, dan component modeling yang dapat digunakan pada semua proses melalui siklus hidup pengembangan perangkat lunak. Maka dari itu di sini penulis akan memodelkan Sistem SCADA pengawasan dan pengontrolan IPA dengan bahasa UML .Dari permasalahan diatas ditemukanlah permasalahan sebagai berikut: (1) Bagaimana mengontrol dan mengawasi proses produksi melalui sistem SCADA. (2) Bagaimana memodelkan sistem SCADA IPA Gunung Pangilun dalam sebuah bahasa pemodelan yang berorientasi objek (UML). Tujuan dari terselesaikan nya maslah tersebuat adalah (1) untuk memahami proses pengolahan air bersih juga kegiatan pengontrolan dan pengawasan terhadap proses pengolahan tersebut. (2) Menganalisa kegiatan pengawasan dan pengontrolan IPA dalam memproduksi air bersih. (3) Membuat suatu model System SCADA di Instalasi Pengolahan Air dengan bahasa UML untuk kegiatan pengawasan dan pengontrolan di IPA. (4) Membangun aplikasi sistem SCADA untuk IPA PDAM Kota Padang. (5) Menguji aplikasi sistem SCADA untuk melakukan pengawasan di IPA PDAM Kota Padang. Dari hasil penelitian ini diharapkan dapat memberikan mamfaat antara lain :

a. Dengan menerapkan sistem SCADA di IPA dapat menigkatkan kuantitas, kualitas, dan kontiniunitas dari produksi air bersih di IPA tersebut.

b. Mengurangi biaya operasional dari kegiatan pengawasan dan pengontrolan dari proses pengolahan di IPA.

c. Mengurangi resiko kegagalan proses karena terlambat mengetahui apabila terjadi kejanggalan dari proses pengolahan karena dapat di ketahui dengan cepat melalui sistem SCADA. 


\section{Metodologi Penelitian}

1. Instalasi Pengolahan Air (Ipa)

Instalasi Pengolahan Air (IPA) merupakan suatu bangunan yang digunakan untuk mengolah air bersih. Komponen-komponen yang menyusun sebuah IPA dapat dilihat pada gambar berikut.

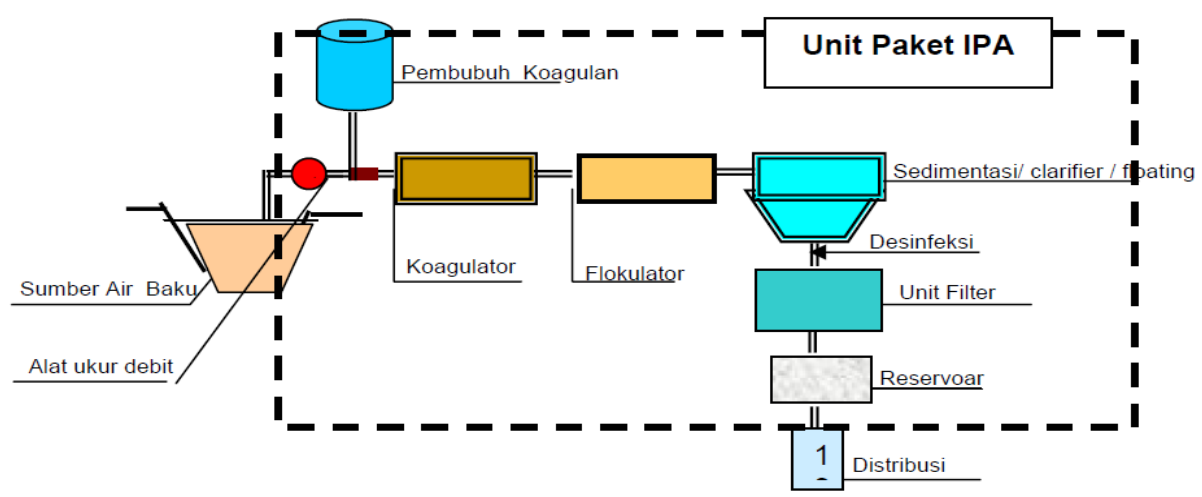

Gambar 1. Unit Paket IPA (SNI 6773:2008)

Proses pengolahan air bersi melalui beberapa tahap yaitu :

1. Intake

Intake merupakan awal dari proses sebuah IPA. Dari intake ini air baku akan diteruskan ketempat penampungan sementara untuk proses selanjutnya. Volume air yang berada dalam bak penampungan sementara harus dijaga agar tetap stabil, sehingga proses pengolahan air dapat berlansung terus menerus.

2. Prasedimentasi

Proses ini dilakukan bertujuan untuk mengendapkan partikel kasar atau partikel diskret yaitu pertikel yang tidak mengalami perubahan bentuk selama mengendap di dalam air.

3. Koagulasi

Air yang berada di bak penampung sementara dipompakan ke bak koagulan untuk diberi koagulan. Pada bak koagulan diharapkan partikel-partikel koloid dapat menjadi partikel flok yang lebih besar sehinga mudah mengendap. Selain ditambahkan koagulan juga dilakukan pengadukan dengan cepat menggunakan mixer, dengan tujuan untuk mencampur antara koagulan dengan koloid.

Penambahan zat koagulan akan menyebabkan turunnya $\mathrm{pH}$ air baku dari target $\mathrm{pH}$ yang diinginkan. Oleh karena itu maka disini juga ditambahkan zat kimia lainnya untuk menaikkan $\mathrm{pH}$ air baku tersebut. Penambahan zat kimia ini menggunakan pompa yang disebut dosing pump yang bertujuan untuk memompakan zat kimia kedalam bak koagulan. Kecepatan dari dosing pump ini dapat diatur sesuai dengan kebutuhan.

4. Flokulasi dan Sedimentasi

Dari bak koagulasi air dilairkan keunit flokulasi dan sedimentasi secara gravitasi. Sistem sedimentasi yang digunakan adalah sistem cone dengan aliran vertikal (upflow) yang terdiri dari 2 bak yang disusun secara seri. Dalam bak yang berbentuk cone dilakukan pengadukan lambat dengan menggunakan mixer yang bertujuan membentuk flok-flok yang lebih besar sehingga dapat diendapkan pada unit sedimentasi. Proses sedimentasi dilakukan setelah proses upflow flokulasi, 
yaitu setelah partikel-partikel yang lebih kecil bergabung atau tersedimentasi pada partikel-partikel yang lebih besar pada sludge blanket. Dan selanjutnya air dialirkan secara gravitasi ke tangki filter untuk proses filtrasi

5. Filtrasi

Filtrasi yang dipakai adalah rapid sand filter atau saringan pasir cepat. Proses filtrasi dimaksudkan untuk menyisihkan partikel koloid yang tidak dapat disisihkan pada proses sebelumnya dan juga untuk mengurangi jumlah bakteri organisme lain.

6. Desinfeksi

Proses ini bertujuan membunuh bakteri patogen yang ada dalam air. Desifektan air dapat dilakukan dengan berbagai cara antara lain dengan pemanasan, penyinaran sinar UV, dan dengan senyawa kimia.

7. Reservoir

Hasil dari proses pengolahan ditampung di reservoir sebelum didistribusikan ke rumah pelanggan.

\section{SCADA (Supervisory Control And Data Aquisition)}

SCADA adalah suatu sistem yang dirancang untuk melakukan pengawasan dan pengendalian suatu proses secara terintegrasi, yang mencakup fungsi monitoring dan pengumpulan data. Supervisory Control mencakup kemampuan untuk melakukan perintah Start / Stop, mengubah parameter suatu proses serta mengubah set point alarm. Sedangkan Data Acquisition merupakan suatu metoda yang digunakan untuk mengakses dan mengontrol informasi atau data dari proses atau peralatan yang diawasi dan di kontrol. Data tersebut kemudian dikirimkan kelokasi yang berbeda melalui suatu media komunikasi. Dalam suatu sistem SCADA biasanya terdiri dari komponen-komponen sebagai berikut :

1. Unit terminal jarak jauh (Remote Station)

Merupakan suatu instrumen yang lansung dihubungkan dengan alat yang diawasi dan dikontrol. Remote Station memberikan kemampuan untu mengontrol dan mengambil data dari peralatan yang dimonitor kemudian mengirimkannya ke pusat kendali SCADA. Remote Station dapat berupa Programable Logic Control (PLC) maupun Remote Terminal Unit (RTU).

Perbedaan antara PLC dan RTU adalah dari segi media komunikasi dan dalam memprogram alat tersebut. PLC tidak di menyediakan komunikasi data dengan wireless biasanya digunakan pada plant/pabrik kecil. Sedangkan RTU menyediakan komunikasi data dengan wireless tetapi dalam pemrogramannya tidak sebaik PLC.

2. Human Machine Interface (HMI)

Merupakan suatu interface antara operator dengan controller. HMI berupa penel kontrol yang didalamnya terdapat numerik keypad dan layar LCD yang menampilakan pesan. Numerik keypad digunakan untuk memasukan data kedalam sistem kemudian LCD menampilkan pesannya.

3. Central Monitoring Station (CMS)

Ini merupakan pusat dari sistem SCADA, merupakan suatu tempat pengumpulan data yang diambil dari remote station dan melakukan pengontrolan jika diperlukan. CMS terdiri dari sebuah komputer atau lebih menyediakan informasi atau data dari sitem SCADA.3. 


\section{ANALISA DAN PERANCANGAN SISTEM}

Dari hasil survey ke IPA yang berlokasi di Gunung Pangilun maka dapat ditangkap kebutuhan-kebutuhan terhadap sistem SCADA sebagai berikut :

1. Distribution Chamber

Informasi yang dibutuhkan dilokasi ini :

- Turbidity (tingkat kekeruhan air)

- pH (tingkat keasaman air)

Dibutuhkan penambahan dosis larutan zat kimia secara otomatis oleh sistem ketika kualitas air baku diluar yang disarankan:

- Alumunium Sulfat $\left(\mathrm{Al}_{2} \mathrm{SO}_{4} 6 \mathrm{H}_{2} \mathrm{O}\right)$

- Kapur tohor $\left(\mathrm{CaCO}_{3}\right)$

2. Outlet Acellator

Informasi yang dibutuhkan disini :

- Turbidity (tingkat kekeruhan air)

- pH (tingkat keasaman air)

3. Penyaringan dengan Sand Filter

Disini dibutuhkan informasi kekeruhan air. Kontrol yang dibutuhkan adalah sebagai berikut :

- Inlet valve

- Outlet valve

- Backwash valve

- Pompa blower

- Pompa backwash

4. Outlet sand filter

Dibutuhkan penambahan larutan zat kimia secara otomatis berdasarkan hasil pembacaan di outlet acellator. Zat kimia yang ditambahkan disini adalah :

- Kapur Tohor $\left(\mathrm{CaCO}_{3}\right)$

- Kaporit $\left(\mathrm{CaO}(\mathrm{Cl})_{2}\right)$

5. Reservoar

Informasi yang diperlukan pada reservoar adalah sebagai berikut :

- tingkat kekeruhan air

- $\mathrm{pH}$

- debit air di pipa induk distribusi

- Level air

- residual chlor.

Usecase Diagram

Untuk menganalisa kebutuhan tersebut diatas maka kebutuhan-kebutuhan terhadap sistem dapat dimodelkan dalam bentuk use case. Use case diagram terdiri dari aktor dan use case. Dalam sistem SCADA untuk IPA ini terdapat 3 (tiga) aktor yang berperan menjalankan use case. Aktor tesebut yaitu :

Tabel.1 Aktor yang terdapat dalam sistem

\begin{tabular}{|l|l|ll|}
\hline \multicolumn{1}{|c|}{ Aktor } & \multicolumn{4}{|c|}{ Defenisi } \\
\hline Operator & Orang/user yang mengoperasikan sistem. \\
\hline OPC Server & $\begin{array}{l}\text { Merupakan komputer server yang terkoneksi melalui jaringan } \\
\text { komunikasi. }\end{array}$ \\
\hline
\end{tabular}


UPI YPTK Jurnal KomTekInfo Vol. 5, No. 1, Juni 2018, Hal. 58-69 ISSN :2356-0010 | eISSN :2502-8758 Copyright@2018 by LPPM UPI YPTK Padang

\begin{tabular}{|l|l|}
\hline Field devices & $\begin{array}{l}\text { Field devices merupakan generalisasi dari sensor-sensor, pompa, valve } \\
\text { dan alat ukur yang diletakkan dilokasi-lokasi yang di amati. }\end{array}$ \\
\hline Database & Database merupakan media tempat penyimpanan data-data. \\
\hline
\end{tabular}

Use case diagram dari sistem SCADA untuk IPA secara umum dapat digambarkan seperti gambar 4.3 dibawah ini.

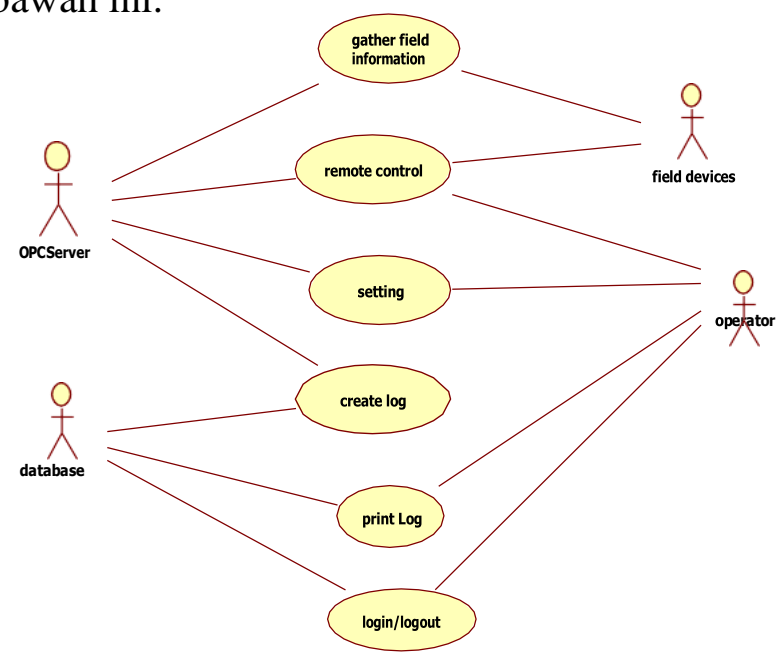

\section{Gambar.2 Use Case Diagram Sistem SCADA untuk IPA}

Beberapa dari use case diatas merupakan generalisasi dari use case yang lebih khusus. Rincian dari generalisasi dapat dilihat pada digram-diagram use case dibawah ini :

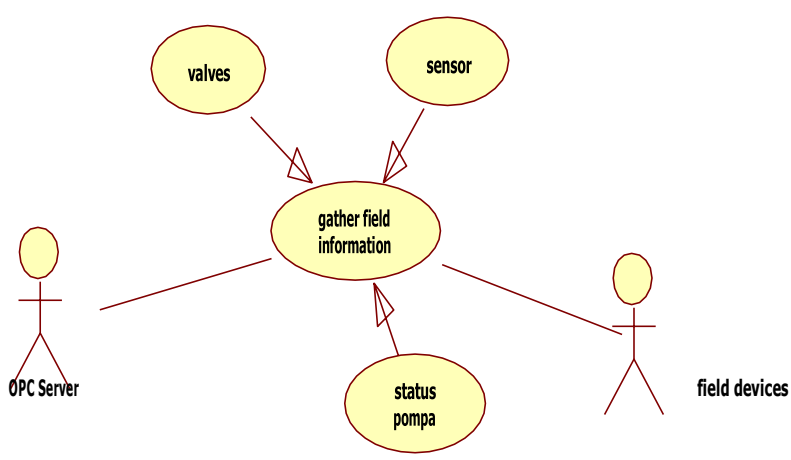

\section{Gambar.3 Generalisasi Use case Gather Field Information}

Gambar 4.4 merupakan rincian use case diagram dari Gather Field Information. Dari use case tersebut dirincikan lagi menjadi 3 (tiga) buah use case yaitu valve, sensor, dan status pompa. Use case ini terdiri dari 2 (dua) aktor yaitu OPC server dan Field Devices. Field Devices membaca data-data dilapangan dan dikirimkan ke sistem kemudian $O P C$ server mengoleksi data tersebut untuk di tampil kan atau di disimpan dalam bentuk $L o g$ di database 

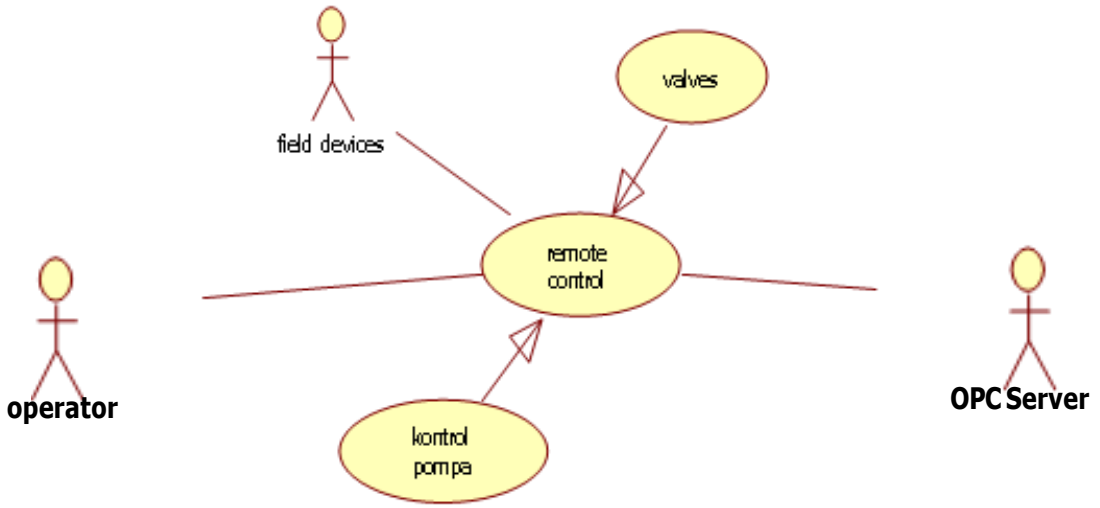

\section{Generalisasi Use Case Remote Controle}

Pada gambar Generalisasi Use case Remote Controle terlihat rincian dari use case tersebut. Use case ini menerangkan bagaimana operator dan OPC Sever berkolaborasi untuk melakukan pengontrolan terhadap alat-alat dilapangan (field devices). Alat-alat yang dapat di kontrol dari jarak jauh (Remote Controle) yaitu pompa, dan valve.

\section{Class Diagram}

Class diagram merupakan diagram yang menunjukan class-class yang ada dari sebuah sistem dan hubungannya secara logika serta struktur statis dari sebuah sistem. Class diagram bertujuan untuk menampilkan class serta paket-paket yang ada di dalam sistem. Class diagram dari sistem ini dapat dilihat pada gambar berikut

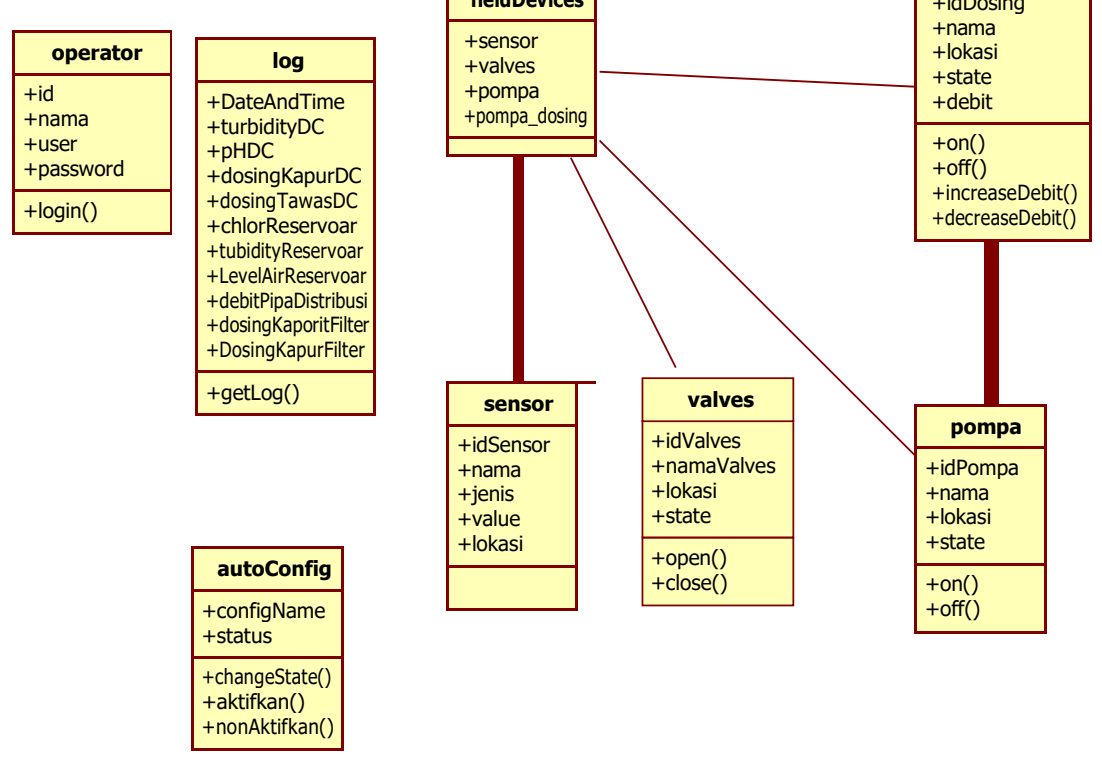

Gambar.4 Generalisasi Use case Gather Field Information 


\section{IMPLEMENTASI DAN PENGUJIAN}

Dalam membangun atau mengimplementasikan rancangan kedalam bentuk prototype dibutuhkan perangkat komputer dan tool-tool yang digunakan untuk mendukung pembuatan prototype. Prototype yang dibangun berbentuk windows base dengan menggunakan Visual Studio 2010. Bahasa program yang digunakan adakah bahasa $C \#$ (C sharp). Untuk database server digunakan $M y S Q L$ dan untuk simulasi perangkat-perangkat SCADA digunakan OPC System .Net.

1. Desain Antar Muka

Untuk tampilan utama dari sistem ini disebut dangan HMI (Human Manchine Interface). Bentuk dari tampilan utama dapat dilihat pada gambar berikut:

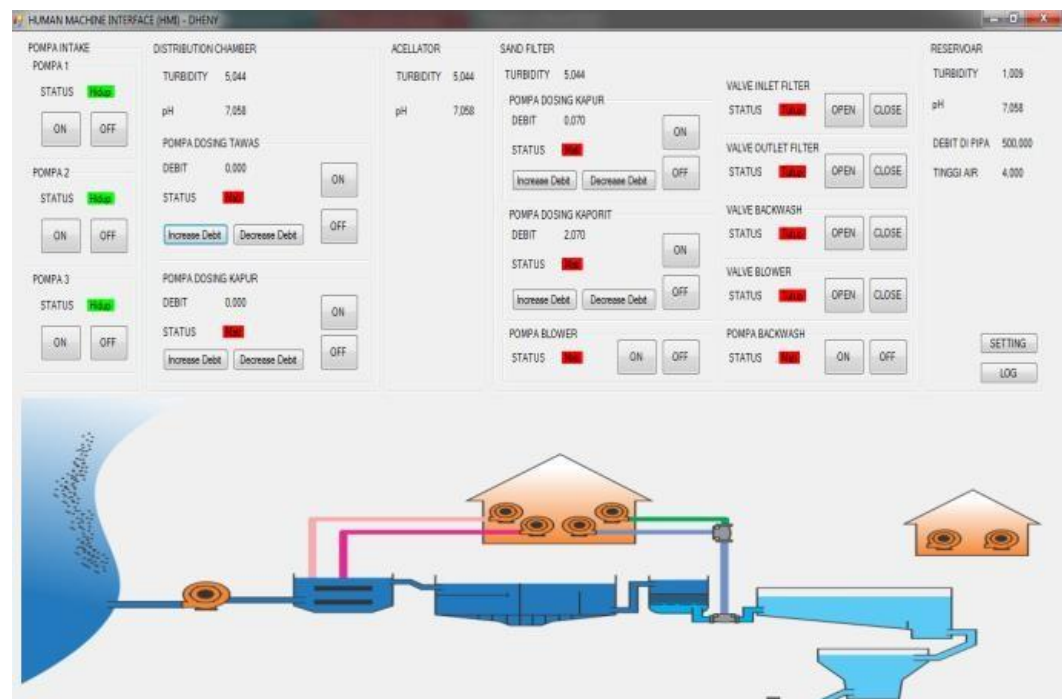

Gambar.5 Tampilan Utama Sistem (HMI)

Pada form ini operator dapat melakukan monitoring sistem dan juga dapat melakukan kontrol terhadap perangkat-perangkat dilapangan. Semua informasi yang dibutuhkan dari proses pengolahan air dapat diketahui melalui form ini. Operator juga dapat merobah setting dari sistem dengan menekan tombol setting yang ada pada form ini. Desain tampilan dari form setting dapat dilihat pada gambar 5.2.

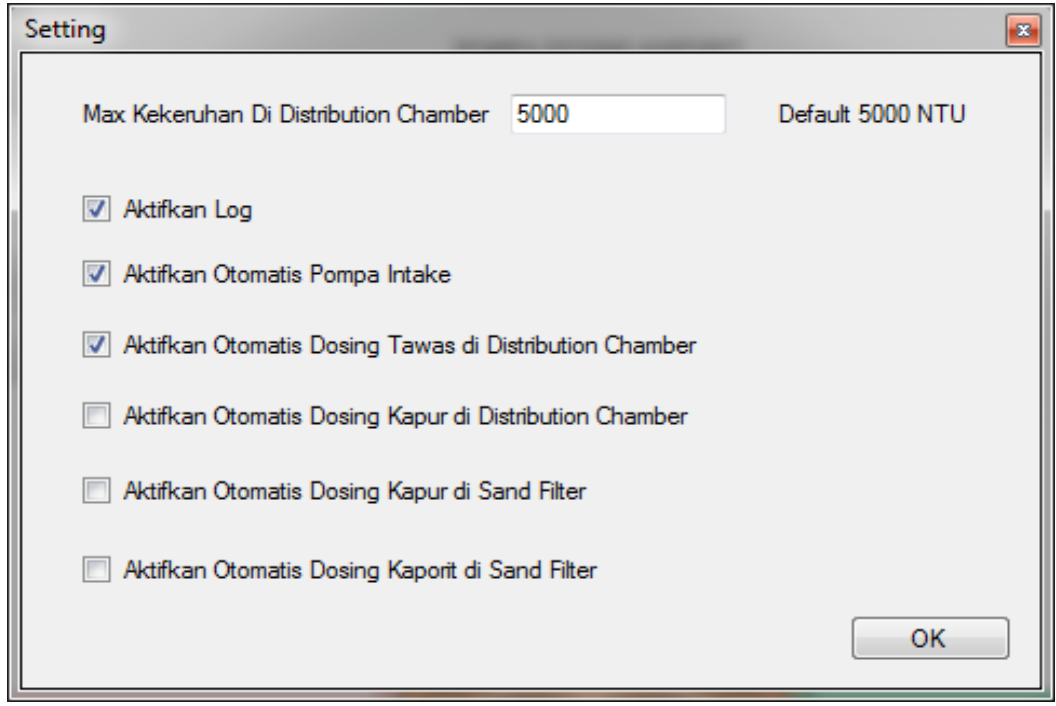

Gambar.6 Tampilan Form Setting

Di sini operator dapat merubah setting sesuai dengan kebutuhan. Dengan menekan 
UPI YPTK Jurnal KomTekInfo Vol. 5, No. 1, Juni 2018, Hal. 58-69 ISSN :2356-0010 | eISSN :2502-8758

Copyright@2018 by LPPM UPI YPTK Padang

tombol "OK" maka sistem akan menyimpan perobahan setting. Dari tampilan utama sistem operator juga dapat mencetak log yang telah tersimpan di database. Desain tampilan untuk mecetak log dapat dilihat pada gambar berikut:

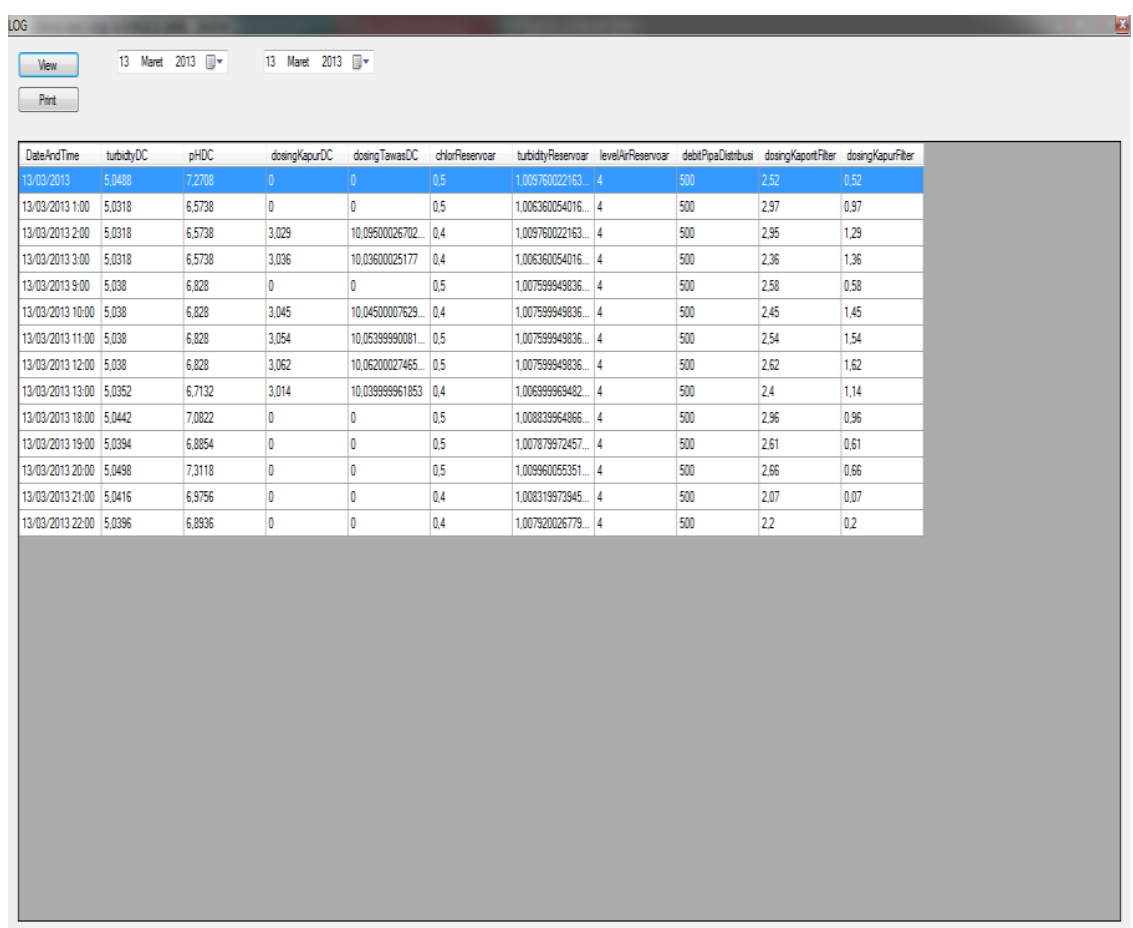

Gambar.7 Tampilan Form Print Log

Dengan menekan tombol print maka akan muncul form print preview. Untuk tampilan print review dapat dilihat pada gambar berikut:

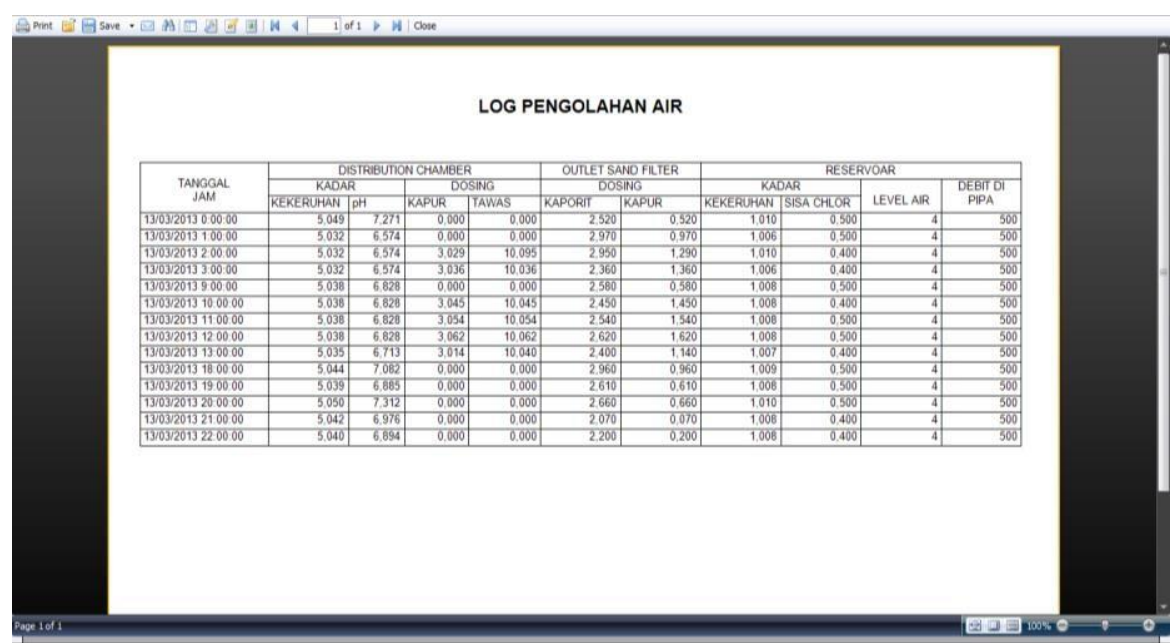

Gambar.8 Tampilan Print Log

2. Tampilan Form Login

Pada awal memulai sistem operator sebelumnya harus melakukan login terlebih dahulu. Desain tampilan dari Login Form dapat dilihat pada gambar. 


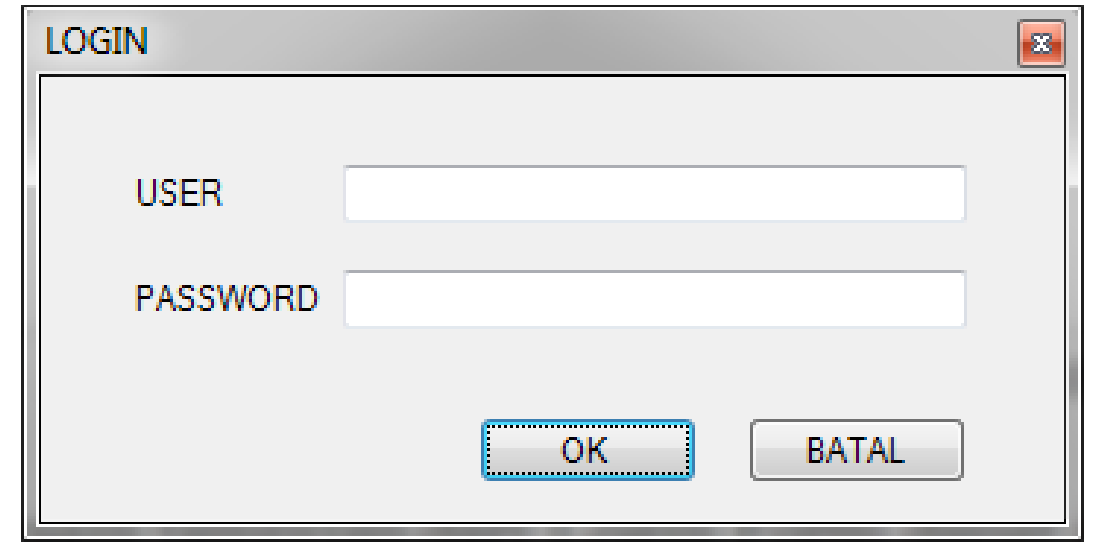

\section{Gambar.9 Tampilan Print Log}

Class pompa dosing merupakan representasi objek pompa dosing di kode program. Class ini adalah turunan dari class pompa. Perbedaan class ini adalah menambahkan 2 (dua) prosedur yaitu "increasedebit" dan "decreasedebit". Atribut dan prosedure lainnya di turunkan dari class induknya. Class log merupakan representasi objek log di kode program. Objek log merupakan tabel yang ada di database. Setiap atribut pada class ini mewakili field-field yang ada pada tabel log. Class autoconfig merupakan representasi objek autoconfig di kode program. Objek autoconfig mewakili table settingdosing yang ada di database. Setiap atribut pada class ini mewakili field-field yang ada pada tabel settingdosing.

\section{Pengujian}

Tahap pengujian merupakan bagian yang penting dalam siklus pembangunan perangkat lunak. Tujuan dari pengujian ini adalah untuk menjamin bahwa perangkat lunak yang dibangun memiliki kualitas yang baik, serta mampu memenuhi kebutuhan pengguna. Pengujian dilakukan dengan metode pengujian black box yaitu pengujian yang berfokus pada persyaratan fungsional perangkat lunak yang dibuat. Untuk melakukan pengujian ini dilakukan dengan kasus uji sesuai dengan diagram use case. Kasus-kasus uji tersebut dapat dilihat pada tabel-table berikut ini :

Tabel.2 Tabel Pengujian Login

\begin{tabular}{|c|c|c|c|}
\hline \multicolumn{4}{|c|}{ Kasus dan Hasil Uji (User dan Password Benar) } \\
\hline Kasus & $\begin{array}{l}\text { Yang } \\
\text { Diharapkan }\end{array}$ & Pengamatan & Kesimpulan \\
\hline $\begin{array}{l}\text { Login dengan } \\
\text { user dan } \\
\text { password benar }\end{array}$ & $\begin{array}{l}\text { Operator berhasil } \\
\text { login }\end{array}$ & Operator berhasil login & Diterima \\
\hline \multicolumn{4}{|c|}{ Kasus dan Hasil Uji (User dan Password Salah) } \\
\hline Kasus & $\begin{array}{c}\text { Yang } \\
\text { Diharapkan }\end{array}$ & Pengamatan & Kesimpulan \\
\hline $\begin{array}{l}\text { Login dengan } \\
\text { user dan } \\
\text { password salah }\end{array}$ & Login ditolak & Login di tolak & Diterima \\
\hline
\end{tabular}


UPI YPTK Jurnal KomTekInfo Vol. 5, No. 1, Juni 2018, Hal. 58-69 ISSN :2356-0010 | eISSN :2502-8758

Tabel.3 Uji Hasil

\begin{tabular}{|l|l|l|l|}
\hline \multicolumn{4}{|c|}{ Kasus dan Hasil Uji } \\
\hline \multicolumn{1}{|c|}{ Kasus } & Yang Diharapkan & \multicolumn{1}{|c|}{ Pengamatan } & $\begin{array}{l}\text { Kesimpu } \\
\text { lan }\end{array}$ \\
\hline $\begin{array}{l}\text { Menampilkan informasi- } \\
\text { informasi dilapangan }\end{array}$ & $\begin{array}{l}\text { Semua informasi } \\
\text { dilapangan dapat } \\
\text { terlihat di form } \\
\text { HMI }\end{array}$ & $\begin{array}{l}\text { Informasi } \\
\text { lapangan dapat } \\
\text { terlihat di form } \\
\text { HMI }\end{array}$ & Diterima \\
\hline
\end{tabular}

Tabel.4 Pengujian Monitoring

\begin{tabular}{|l|l|l|l|}
\hline \multicolumn{4}{|c|}{ Kasus dan Hasil Uji } \\
\hline \multicolumn{1}{|c|}{ Kasus } & Yang Diharapkan & \multicolumn{1}{|c|}{ Pengamatan } & Kesimpulan \\
\hline $\begin{array}{l}\text { Menghidupkan } \\
\text { bompa }\end{array}$ & Pompa hidup & Pompa hidup & Diterima \\
\hline $\begin{array}{l}\text { Mematikan } \\
\text { pompa }\end{array}$ & Pompa mati & Pompa mati & Piterima \\
\hline Membuka valve & Status valve terbuka & Valve terbuka & Diterima \\
\hline Menutup valve & Status valve tertutup & Valve tertutup & Diterima \\
\hline $\begin{array}{l}\text { Menambah debit } \\
\text { pompa dosing }\end{array}$ & $\begin{array}{l}\text { Pebit pompa dosing } \\
\text { pertambah }\end{array}$ & Pebit pompa dosing & Piterima \\
\hline $\begin{array}{l}\text { Menurunkan } \\
\text { debit pompa } \\
\text { dosing }\end{array}$ & Pebit pompa dosing & Pebit pompa dosing & Diterima \\
\hline
\end{tabular}

Tabel.5 Pengujian Remote Controle

\begin{tabular}{|c|c|l|l|}
\hline \multicolumn{4}{|c|}{ Kasus dan Hasil Uji } \\
\hline Kasus & Yang Diharapkan & Pengamatan & Kesimpulan \\
\hline Merubah setting & Setting berubah & Setting berubah & Diterima \\
\hline
\end{tabular}

Tabel.6 Pengujian Setting

\begin{tabular}{|l|l|l|l|}
\hline \multicolumn{5}{|c|}{ Kasus dan Hasil Uji } \\
\hline \multicolumn{1}{|c|}{ Kasus } & Yang Diharapkan & Pengamatan & Kesimpulan \\
\hline Menampilkan $\log$ & Log tampil & Log tampil & Diterima \\
\hline Mencetak $\log$ & Log tercetak & Log tercetak & Diterima \\
\hline
\end{tabular}


Tabel.7 Pengujian Setting

\begin{tabular}{|l|l|l|l|}
\hline \multicolumn{5}{|c|}{ Kasus dan Hasil Uji } \\
\hline \multicolumn{1}{|c|}{ Kasus } & Yang Diharapkan & Pengamatan & Kesimpulan \\
\hline Menampilkan $\log$ & Log tampil & Log tampil & Diterima \\
\hline Mencetak $\log$ & Log tercetak & Log tercetak & Diterima \\
\hline
\end{tabular}

\section{Tabel.8 Pengujian Print Log}

\begin{tabular}{|l|l|l|l|}
\hline \multicolumn{4}{|c|}{ Kasus dan Hasil Uji } \\
\hline \multicolumn{1}{|c|}{ Kasus } & \multicolumn{1}{|c|}{ Yang Diharapkan } & \multicolumn{1}{c|}{ Pengamatan } & Kesimpulan \\
\hline $\begin{array}{l}\text { Menyimpan log } \\
\text { di database }\end{array}$ & $\begin{array}{l}\text { Log tersimpan di } \\
\text { database }\end{array}$ & $\begin{array}{l}\text { Log tersimpan } \\
\text { di database }\end{array}$ & Diterima \\
\hline
\end{tabular}

\section{Kesimpulan}

Dari table-tabel diatas dapat disimpulkan semua fungsional sistem telah sesuai dengan yang diharapkan. Ini dapat terlihat dari hasil kesimpulan masing-masing kasus uji yang dilakukan terhadap sistem

\section{Referensi}

[1] R. Kirubashankar, K. Krishnamurthy, J. Indra, B.Vignesh, 2011, "Design and Implementation of Web Based Remote Supervisory Control and Information System” International Journal of Soft Computing and Engineering (IJSCE)J. Cohen, "Statistical power analysis for the behavioral sciences," 2nd ed., 1988.

[2] Rajesh Singla and Arun Khosla, 2012, "Intelligent Security System for HMI in SCADA Applications", International Journal of Modeling and Optimization

[3] Rajeev Kumar, M.L.Dewal, 2010, “Multi-Supervisory Control and Data Display”, International Journal of Computer Applications

[4] V.Rajeswari, Prof.Y.Rajeshwari, Dr.L.Padma Suresh, 2012, "Real- Time Implementation of Hydroelectric Power Plant Using PLC and SCADA" International Journal of Engineering Research and Applications (IJERA)

[5] Bindu Pillai, Vishal Mehta, Nilam Patel, 2012, "Development of Supervisory Control and Data Acquisition System for Laboratory Based Mini Thermal Power Plant Using LabVIEW"International Journal of Emerging Technology and Advanced Engineering

[6] A. Daneels, W.Salter, 1999, "WHAT IS SCADA?" International Conference on Accelerator and Large Experimental Physics Control Systems

[7] Sri Dharwiyanti, 2003, "Pengantar Unified Modeling Language (UML)" Kuliah Umum IlmuKomputer.Com

[8] Grady Booch, James Rumbaugh, Ivar Jacobson, 1998, The Unified Modeling Language User Guide, Addison Wesley

[9] Murray Cantor, 1998, Object-Oriented Project Management with UML, John Wiley \& Sons, Inc

[10] Addison-Wesley, 1999, "The Unified Modeling Language Reference Manual" 